\title{
KARAKTERISTIK DAN VARIABILITAS PARAMETER-PARAMETER OSEANOGRAFI LAUT JAWA HUBUNGANNYA DENGAN DISTRIBUSI HASIL TANGKAPAN IKAN
}

\author{
Jonson Lumban Gaol'1) dan Bambang Sadhotomo²) \\ 1) Peneliti pada Fakultas Perikanan dan Ilmu Kelautan-Institut Pertanian Bogor, Bogor \\ 2) Peneliti pada Balai Riset Perikanan Laut, Muara Baru-Jakarta \\ Teregristrasi I tanggal: 15 Januari 2007; Diterima setelah perbaikan tanggal: 13 Juni 2007; \\ Disetujui terbit tanggal: 25 Juli 2007
}

\begin{abstract}
ABSTRAK
Penelitian kondisi oseanografi Laut Jawa telah dilakukan sejak 90 tahun yang lewat, sehingga data yang tersedia sudah cukup banyak. Studi ini bertujuan untuk menganalisis kembali data suhu dan salinitas yang diperoleh dari basis data world ocean data-2001 serta data deret waktu suhu permukaan laut dan konsentrasi klorofil-a hasil deteksi satelit dari basis data NASA. Analisis deret waktu dilakukan untuk melihat pengaruh musim dan iklim global terhadap lingkungan perairan dan sumber daya ikan di Laut Jawa. Hasil analisis menunjukkan bahwa variasi parameter-parameter oseanografi Laut Jawa dipengaruhi oleh angin muson dan iklim global ENSO dan variasi ini mempengaruhi distribusi ikan.
\end{abstract}

KATA KUNCI: $\quad$ suhu, salinitas, klorofil-a, Laut Jawa, muson, ENSO

ABSTRACT: Characteristics and variabilitys of oceanographic parameters in Java Sea and its relationship with distribution of fish catch. By: Jonson Lumban Gaol and Bambang Sadhotomo

This study based on remote sensing and in situ data, aimed to synthesize the effect of seasonal and interannual changes on the environment of Java Sea and its relationship with distribution of fish. Data of sea surface temperature, salinity, and chlorophyll-a data generated from Word Ocean Data2001 and NASA were used in the analysis. Time series analysis shows that variation of oceanographic parameters in Java Sea are affected by monsoon and ENSO and these variations affected on distribution of fish.

\section{KEYWORDS: $\quad$ temperature, salinity, chlorophyll-a, Java Sea, monsoon, ENSO}

\section{PENDAHULUAN}

Distribusi dan kelimpahan sumber daya hayati di suatu perairan tidak terlepas dari kondisi dan variasi parameter-parameter oseanografi. Oleh karena itu, informasi yang lengkap dan akurat tentang karakter oseanografi suatu perairan sangat diperlukan untuk tujuan pengelolaan sumber daya perairan secara berkelanjutan.

Penelitian oseanografi di Laut Jawa telah dilakukan 90 tahun yang lewat, hal ini terlihat dari posisi-posisi stasiun pengukuran suhu dan salinitas di Laut Jawa yang terdapat dalam basis data word ocean data-2001. Sadhotomo (2006), telah mensintesis dan menggabungkan hasil-hasil survei hidrografi selama tahun 1950 sampai dengan 1970 dan juga dari pengamatan terbaru saat ini. Beberapa studi oseanografi yang lain juga telah dilakukan di Laut Jawa (Potier et al., 1990; Durand \& Petit, 1995).

Studi ini bertujuan untuk menganalisis kembali data oseanografi (suhu dan salinitas) yang terdapat dalam basis data word ocean data-2001 dan ditambah dengan data dari citra satelit yang cukup lengkap baik secara spasial maupun temporal. Tujuan ke-2 dari studi ini adalah untuk menganalisis variabilitas parameter suhu permukaan laut dan konsentrasi klorofil-a dan hubungan dengan perubahan musim dan iklim global seperti ENSO.

\section{BAHAN DAN METODE}

Dalam studi ini digunakan data suhu dan salinitas yang terdapat dalam basis data word ocean data-2001 mulai tahun 1914 sampai dengan 1998. Posisi dari stasiun pengukuran suhu dan salinitas tertera pada Gambar 1. Data dikelompokkan menjadi 2 musim yaitu dari bulan Desember sampai dengan Mei mewakili musim barat dan data bulan Juni sampai dengan Oktober mewakili musim timur. Data suhu permukaan laut dari citra satelit NOAA-AVHRR mulai tahun 1985 sampai dengan tahun 2002 diperoleh dari basis data NASA-JPL dan konsentrasi klorofil-a dari citra SeaWiFS mulai tahun 1997 sampai dengan tahun 2006 dari basis data NASA-Giovanni. Analisis deret 

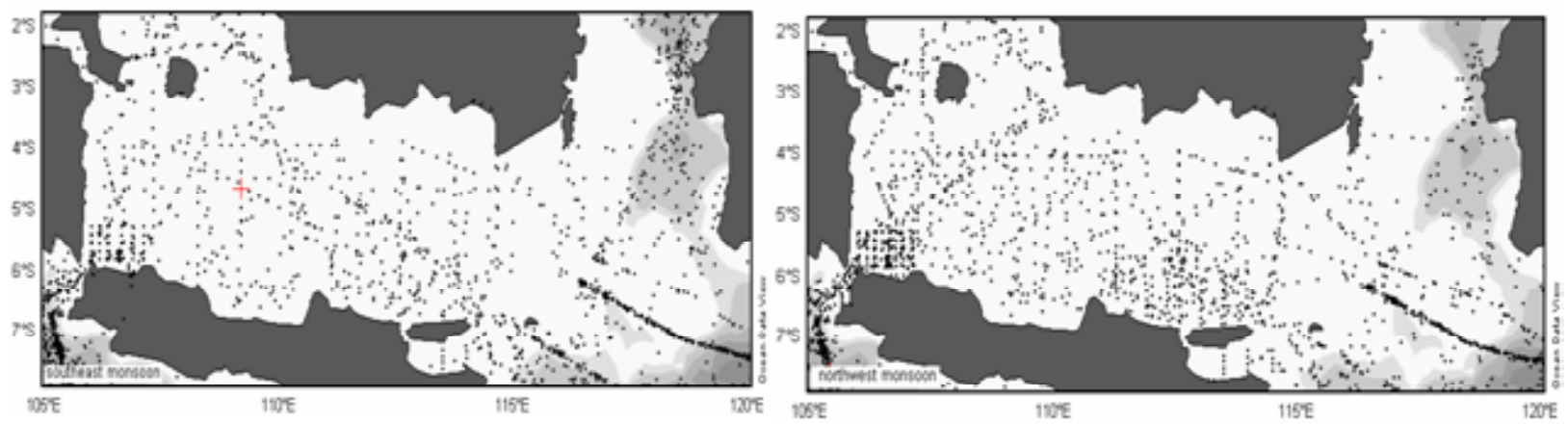

Gambar 1.

a) Posisi stasiun pengukuran suhu dan salinitas di pada musim timur dan b) masim barat di Laut Jawa, tahun 1914 sampai dengan 1998.

Figure 1.

a) Station position of the temperature and salinity observation on east monsoon and b) west monsoon in the Java Sea 1914 - 1988.

waktu digunakan untuk mengetahui variabilitas parameter-parameter oseanografi, sedangkan analisis distribusi spasial secara horisontal dan vertikal dilakukan melalui visualisasi 2 dimensi dengan menggunakan perangkat lunak ocean data view versi $\mathrm{mp}$.

\section{HASIL DAN BAHASAN}

\section{Distribusi Suhu Permukaan Laut}

Rata-rata suhu permukaan laut 8 harian selama 18 tahun di Laut Jawa yang diwakili suhu permukaan laut di wilayah $108-111^{\circ} \mathrm{BT}$ dan 5-8 ${ }^{\circ}$ LS tertera pada (Gambar 2a). Pada umumnya suhu berkisar antara 27 sampai dengan $29^{\circ} \mathrm{C}$, sesuai dengan hasil beberapa peneliti sebelumnya (Saeger et al., 1976; Wyrtki, 1957 dalam Sadhotomo, 2006). Namun, hal yang menarik diperhatikan adalah penurunan suhu permukaan laut yang ekstrim sampai dengan mencapai $25,3^{\circ} \mathrm{C}$ pada tahun 1992.

Hasil analisis spektral suhu permukaan laut menunjukkan ada variasi suhu permukaan laut dengan periode 6 dan 12 bulan adalah representasi dari semi annual dan annual variability, serta periode 32 bulan adalah presentasi dari variabilitas interannual variability (Gambar $2 \mathrm{~b}$ ). Variabilitas ini berhubungan dengan angin muson yang berhembus di atas Laut Jawa dan perubahan iklim global yakni interaksi atmosfer dan laut yang secara nyata terjadi di Lautan Pasifik yang disebut dengan fenomena ENSO.

Pergerakkan angin muson menyebabkan variasi suhu permukaan Laut Jawa, di mana pada saat periode muson tenggara (musim timur), angina, dan arus di Laut Jawa bergerak dari timur ke barat membawa massa air yang relatif lebih dingin masuk ke arah barat yang tergambar dari pola garis isotherm dengan ujung
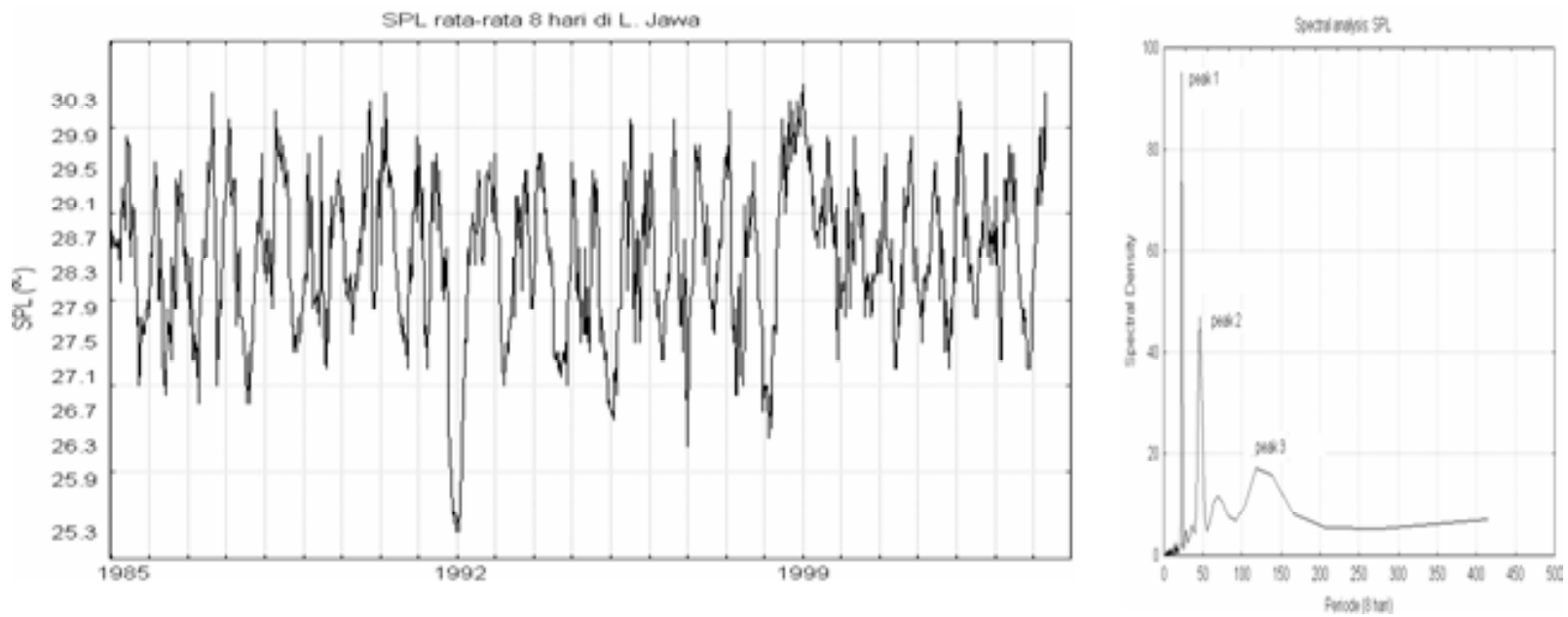

Gambar2. a) Fluktuasi suhu permukaan laut tahun 1985 sampai dengan 2002 di Laut Jawa dan b) densitas spektral.

Figure 2. $\quad$ a) Fluctuation of sea surface temperature in 1985 - 2002 in the Java Sea and b) spectral density. 
lidah terbentuk di bagian barat Laut Jawa (Gambar 3). Rata-rata suhu permukaan laut di Laut Jawa 27,25 sampai dengan $28,25^{\circ} \mathrm{C}$ dengan suhu permukaan laut yang lebih tinggi berada di sebelah barat, sedangkan pada periode muson barat laut (musim barat) massa air dari Laut Cina Selatan mengisi Laut Jawa dan mendorong massa air ke arah timur sesuai dengan arah pergerakkan angin dan arus (Wyrtki, 1961).

Pola distribusi suhu permukaan laut dari citra satelit selama periode 1 tahun (rata-rata dari tahun 1990 sampai dengan 1994) tertera pada Gambar 4a. Awal muson tenggara sekitar bulan Juni sampai

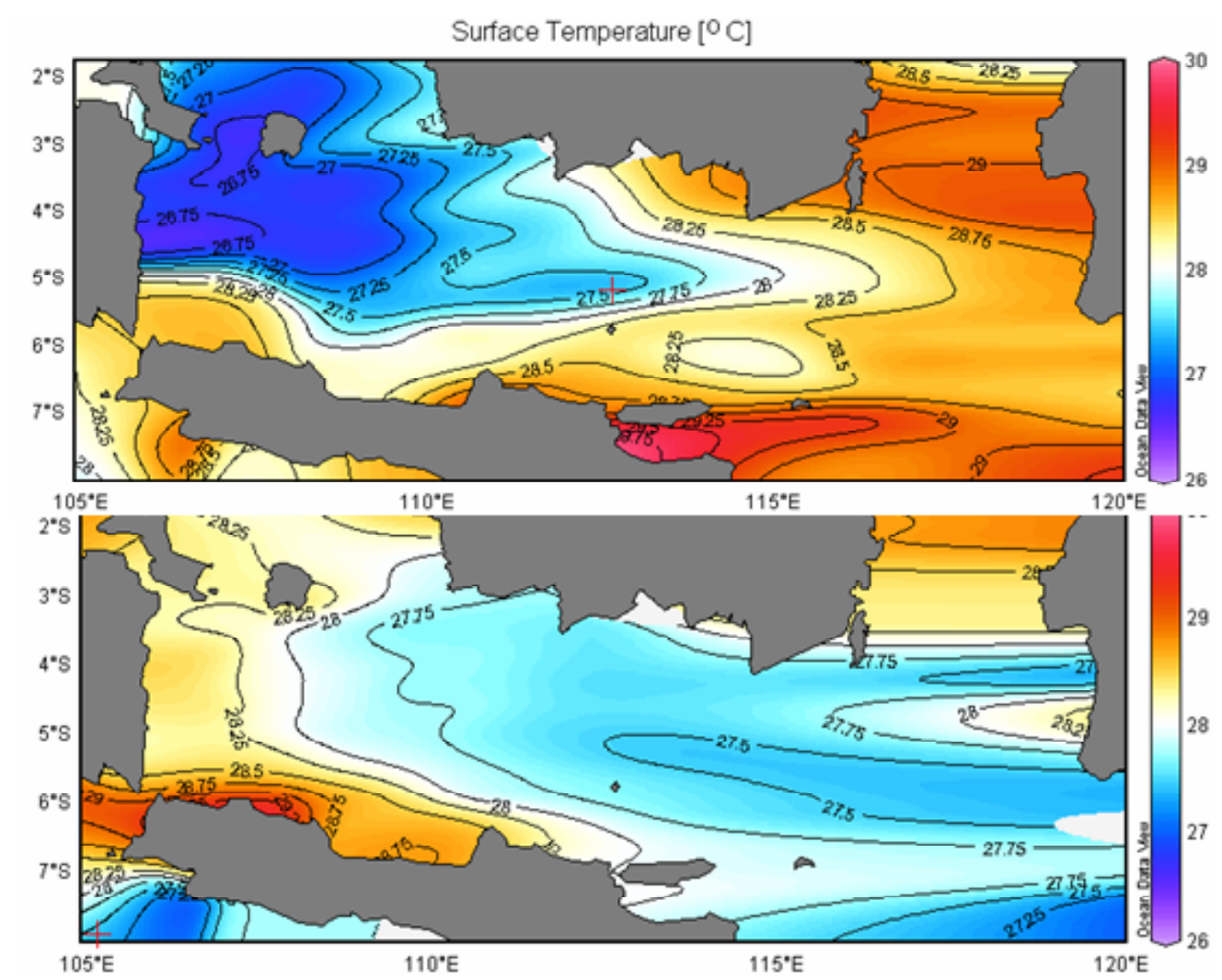

Gambar 3. Distribusi suhu permukaan laut periode musim timur (atas) dan periode musim barat (bawah).

Figure 3. Distribution of sea surface temperature at a periode of east monsoon (above) and on northwest monsoon (below).

dengan Juni massa air dengan suhu 28,5 sampai dengan $28^{\circ} \mathrm{C}$ mulai mengisi wilayah timur Laut Jawa (116 $\left.{ }^{\circ} \mathrm{BT}\right)$ mengantikan suhu antara 29 sampai dengan $30^{\circ} \mathrm{C}$ pada periode muson barat laut. Massa air yang dingin ini bergerak secara gradual ke arah barat dan ujung lidah air dingin $\left(28,0^{\circ} \mathrm{C}\right)$ mencapai bagian barat Laut Jawa (107\% BT) pada bulan Agustus sampai dengan September. Bulan Oktober suhu permukaan laut mulai meningkat kembali sampai dengan bulan Nopember. Bulan Desember sampai dengan Pebruari, suhu menurun kembali yang merupakan pengaruh dari muson barat laut yang mengakibatkan massa air Laut Cina Selatan dengan suhu yang lebih rendah bercampur dan mendorong massa air Laut Jawa dari barat ke timur.

Gambar 4b menunjukkan distribusi (time longitude) suhu permukaan laut mulai tahun 1990 sampai dengan 1994. Periode muson tenggara tahun 1991 terjadi anomali negatif suhu permukaan laut mulai dari 118 sampai dengan $106^{\circ} \mathrm{BT}$ yang merupakan pengaruh dari fenomena ENSO. Walaupun fenomena ini terjadi di Samudra Pasifik tetapi melalui telekoneksi mempengaruhi kondisi klimat di banyak wilayah termasuk di trofis maupun subtrofis (Allan et al., 1996). Menurut Meyers (1996), ENSO menyebabkan pendangkalan lapisan termoklin di Samudra Hindia seiring dengan menurun tinggi paras laut. Penurunan paras laut di Samudra Hindia dapat menyebabkan penurunan paras laut di Laut Jawa, sehingga intrusi air oseanik dengan suhu yang lebih rendah pada periode muson tenggara semakin intensif.

Distribusi vertikal suhu dari permukaan sampai dengan dasar perairan tidak menunjukkan ada 

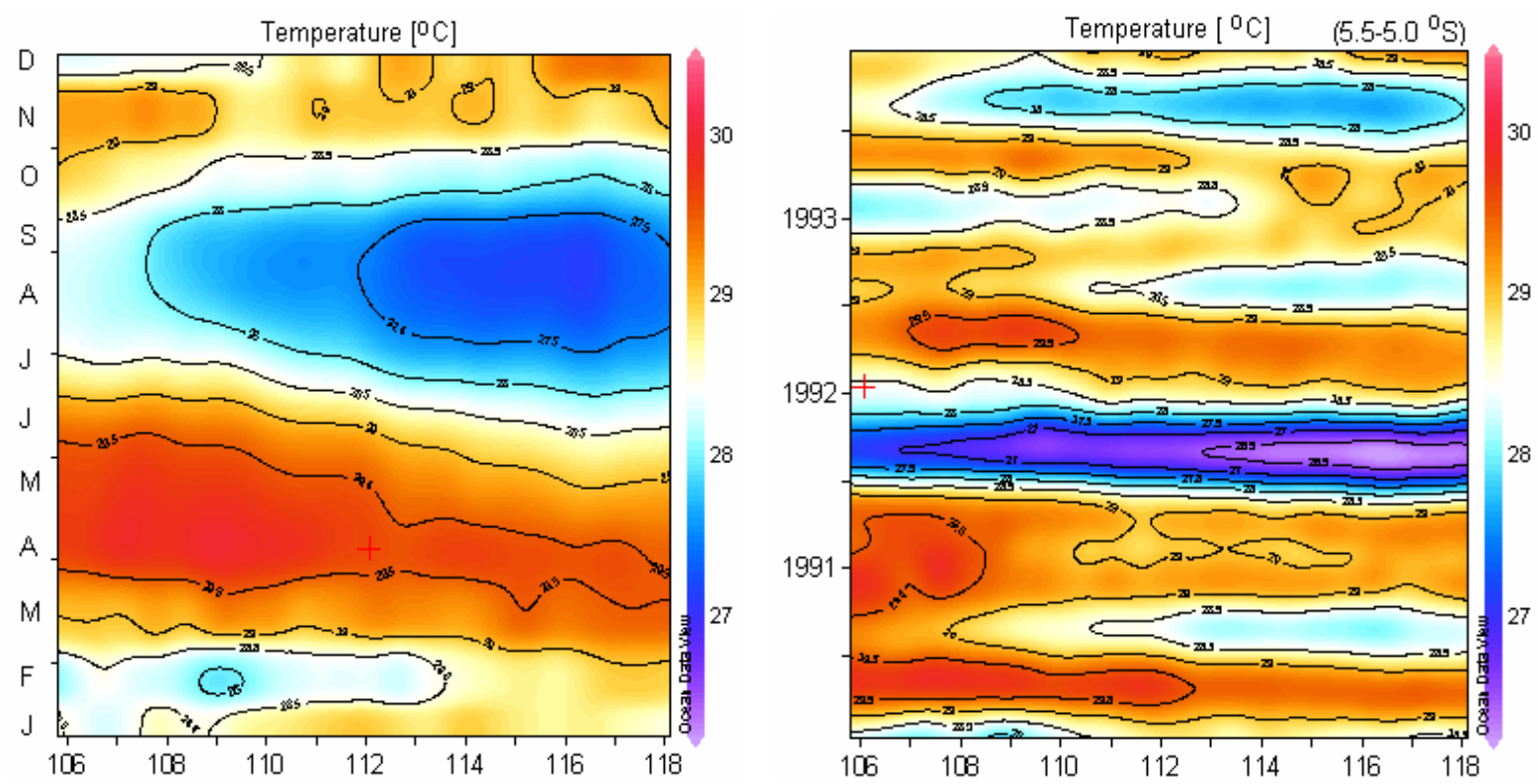

Gambar 4.

a) Time longitude plot suhu permukaan laut bulan Januari sampai dengan Desember dan b) tahun 1990 sampai dengan 1994.

Figure $4 . \quad$ a) Time longitude plot of sea surface temperature on January until December and b) the year 1990 - 1994.

stratifikasi. Intrusi massa air oseanik dari timur ke barat pada periode muson tenggara juga terjadi di seluruh kolom perairan (Gambar 5). Stratifikasi suhu hanya terlihat di luar bagian timur Laut Jawa yang

berbatasan dengan Laut Flores. Periode muson tenggara massa air di bagian barat Laut Jawa lebih tinggi dari bagian timur, sebaliknya terjadi pada periode muson barat laut.

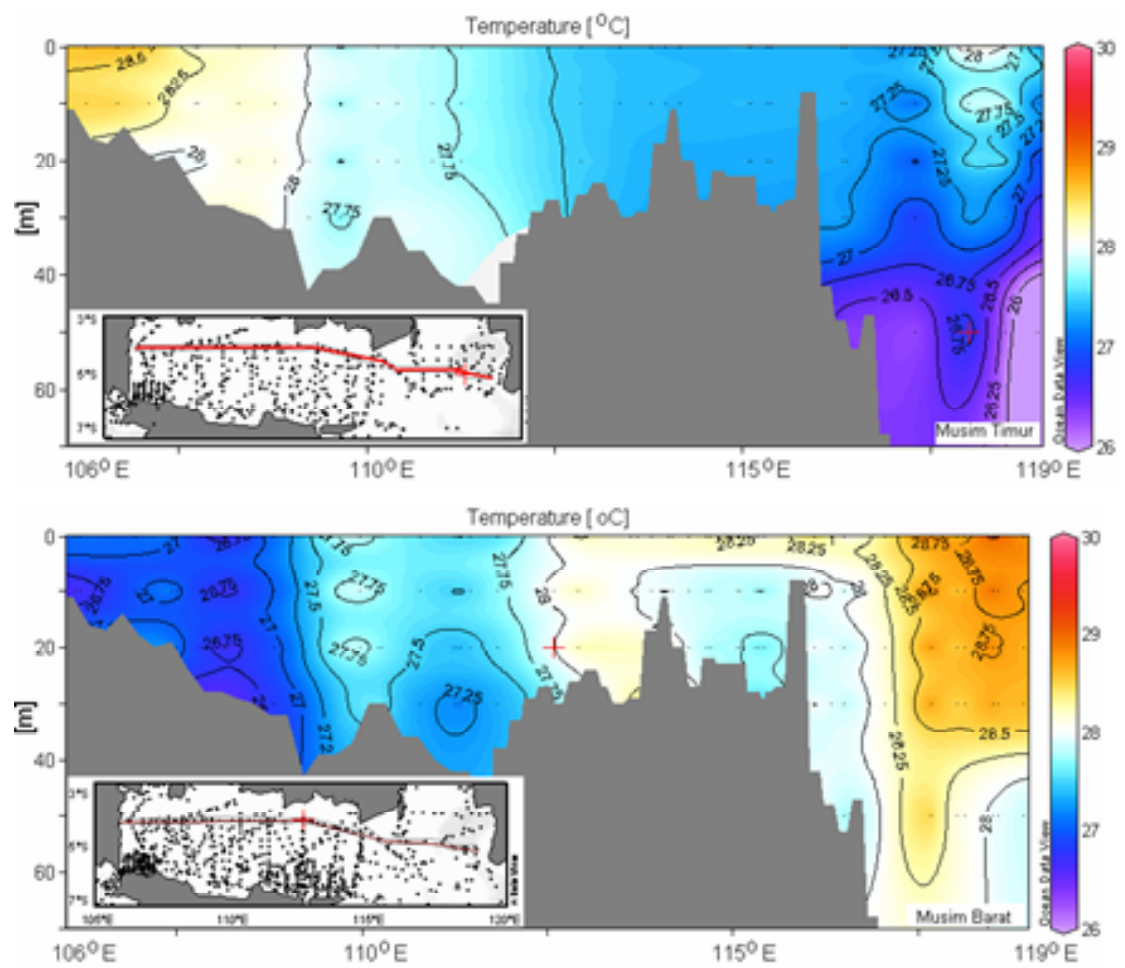

Gambar 5. Distribusi vertikal suhu di Laut Jawa pada waktu musim timur (atas) dan musim barat (bawah). Figure 5. Vertical distribution of temperature of the Java Sea during a period of east monsoon (above) and on west monsoon (below). 


\section{Distribusi Salinitas}

Sebagaimana halnya dengan distribusi suhu permukaan laut, pola distribusi salinitas di Laut Jawa sangat dipengaruhi oleh pergerakkan angin muson. Selama muson tenggara, angina, dan arus datang dari timur dan pada waktu yang sama, air oseanik masuk ke Laut Jawa dan secara gradual mendorong air bersalinitas rendah ke bagian barat dan sebaliknya terjadi pada periode muson barat laut.

Berdasarkan pada pola pergerakkan arus yang dijelaskan oleh Wyrtki $(1957 ; 1961)$, banyak kemungkinan terjadi proses percampuran dan pengaruh dari massa air dari wilayah lain terhadap karakteristik massa air Laut Jawa. Paling tidak ada 2 sumber massa air yang masuk ke Laut Jawa yakni massa air Laut Cina Selatan melintasi Selat Karimata dan yang datang dari Pasifik melalui Laut Flores dan Selat Makassar (Sadhotomo, 2006).

Wyrtki (1956) dalam Sadhotomo (2006) mengklasifikasikan sirkulasi di Laut Jawa ke dalam 3 tipe. Pertama adalah perairan oseanik dengan salintitas lebih dari $34 \%$. Terjadi intrusi massa air salinitas tinggi ini sangat jelas terlihat pada waktu angin muson tenggara berhembus (Gambar 6b). Garis isohaline yang melintang dengan bentuk mengerucut dari timur menuju ke barat menunjukkan pergerakkan massa air oseanik bersalinitas tinggi dari arah timur menuju ke barat sampai dengan ujung lidah massa air salinitas tinggi dapat mencapai posisi $118^{\circ} \mathrm{BT}$.

Massa air ke-2 adalah yang bersalinitas 32 sampai dengan $34 \%$. Massa air itu berasal dari bagian selatan Laut Cina dan bercampur dengan air yang lebih tawar di Laut Jawa. Percampuran massa air ini sangat jelas terlihat pada waktu angin moson barat laut seperti tertera pada Gambar 6a. Ke-3 adalah massa air dengan salinitas kurang dari $32 \%$. Tipe yang lain adalah massa air dari sungai dengan salinitas kurang dari $30 \%$ yang sangat jelas terlihat di pantai selatan Kalimantan dan pantai timur Sumatera.

Proses percampuran massa air selama 1 tahun berdasarkan pada pola distribusi salinitas di Laut Jawa tergambar pada Gambar 7. Bulan Januari sampai dengan Mei pada saat periode angin muson barat laut, pola garis isohaline menunjukkan bahwa massa air bergerak dari barat menuju ke timur. Selama periode ini Laut Jawa dominan diisi massa air dengan salintas rata-rata 30 sampai dengan 32 psu. Sebaliknya, mulai bulan Juni, yang merupakan periode awal muson tenggara, garis isohaline menunjukkan massa air bergerak dari timur ke barat. Pada periode Laut Jawa dominan diisi oleh massa air dengan
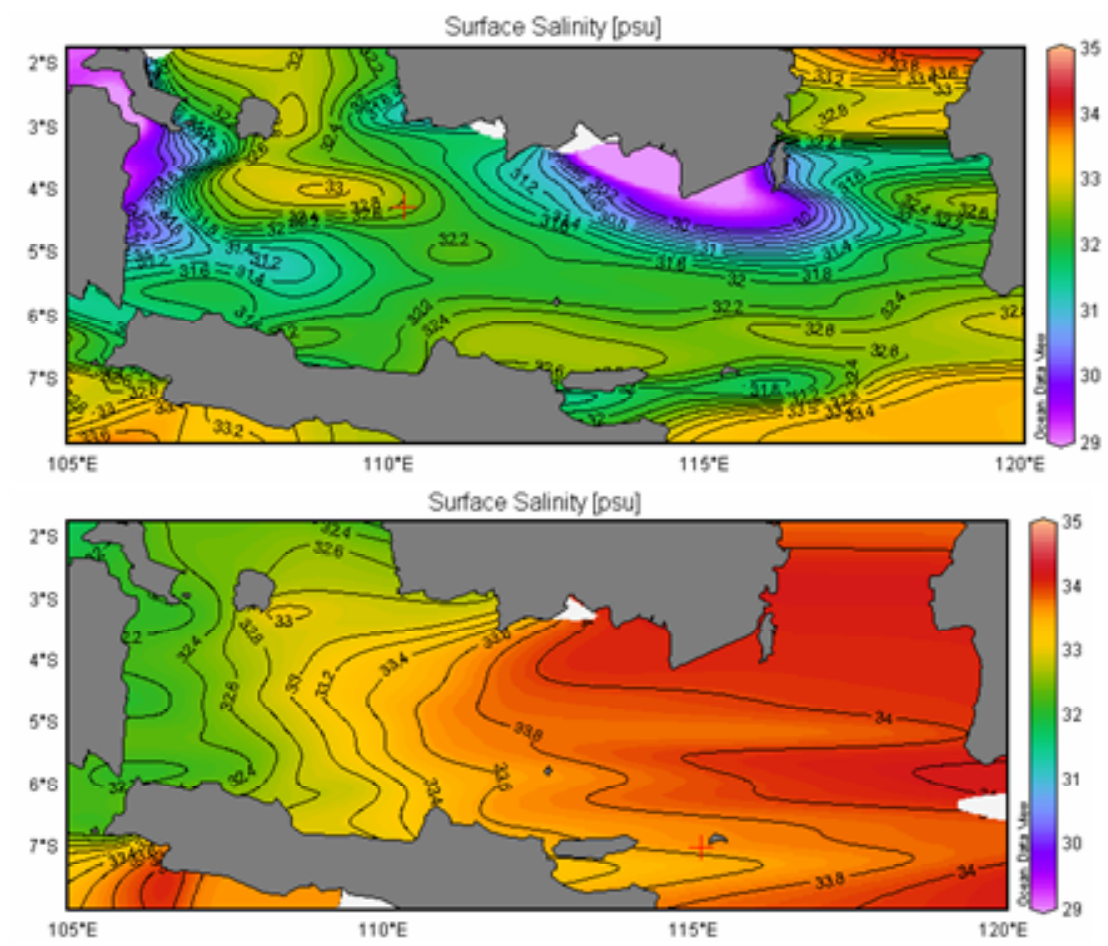

Gambar 6. Distribusi horisontal salinitas musim barat dan (atas) dan musim timur di Laut Jawa (atas). Figure 6. Horizontal distribution of salinity of the Java Sea during a periode of east monsoon (above) and on west monsoon (below). 


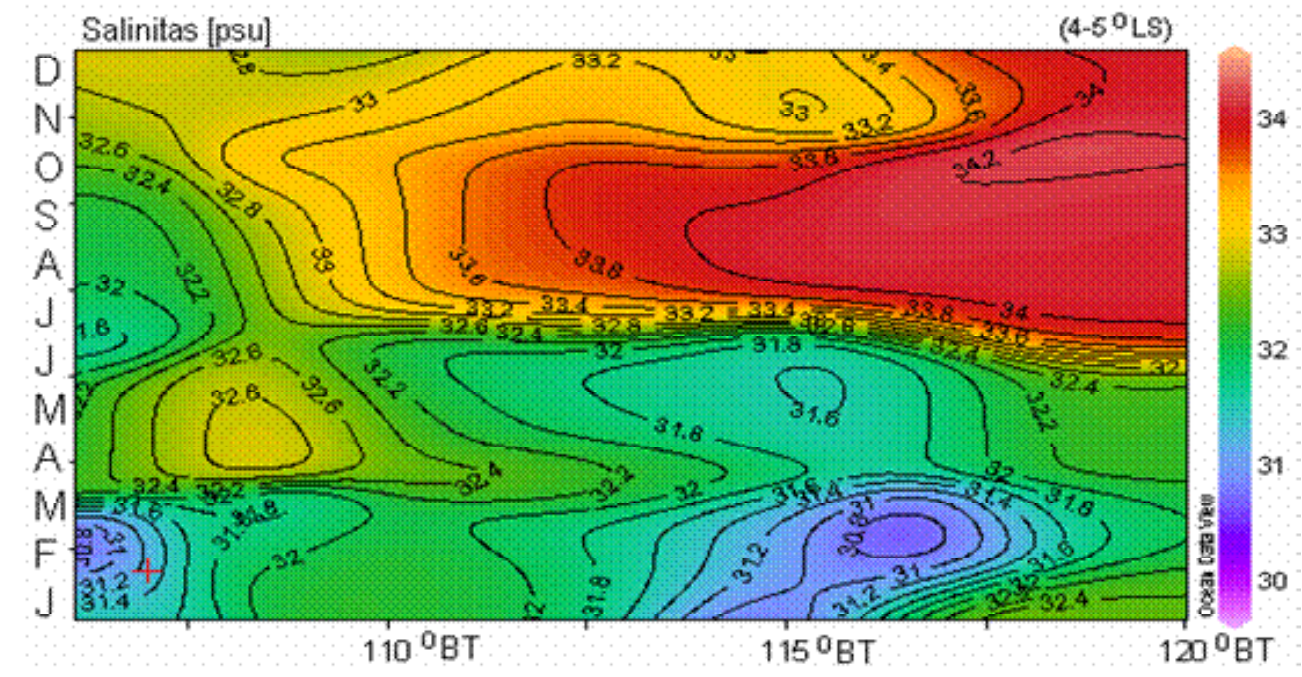

Gambar 7. Time longitude plot (bulan-bujur) salintas permukaan Laut Jawa.

Figure 7. Time longitude plot (month-longitude) of surface salinity in Java Sea.

salintas rata-rata di atas 33 psu. Penetrasi yang paling jauh dari air bersalinitas tinggi ini terjadi pada bulan September sampai dengan Oktober ketika ujung lidah isohaline 34 psu mencapai bagian tengah Laut Jawa dan selama periode ini kisaran nilai salintas antara 32,5 sampai dengan 34,2 psu.

Distribusi vertikal salinitas di perairan Laut Jawa pada posisi 116 sampai dengan $119^{\circ} \mathrm{BT}$ di sekitar $4^{\circ}$ LS pada periode muson barat laut yang merupakan musim penghujan tertera pada Gambar 8a. Secara umum, pola distibusi salinitas permukaan sampai dengan kedalaman dasar perairan tidak menunjukkan ada stratifikasi kecuali di sekitar pantai selatan
Kalimantan. Percampuran massa air tawar dari sungai-sungai yang bermuara ke pantai barat Sumatera dengan massa air salinitas lebih tinggi yang mengalir dari Laut Cina Selatan mengakibatkan salintas di ujung Laut Jawa bagian barat (106 sampai dengan $107^{\circ} \mathrm{BT}$ ) diisi oleh salinitas $<32 \mathrm{psu}$. Pada posisi 107 sampai dengan $110^{\circ}$ BT diisi massa air bersalinitas 33,0 sampai dengan 33,4 psu yang merupakan percampuran dengan massa air Laut Cina Selatan. Pengaruh masukan air tawar dari sungaisungai yang bermuara di pantai selatan Kalimantan (112 sampai dengan $117^{\circ} \mathrm{BT}$ ) terlihat dari distribusi salintas vertikal dari permukaan $<31,0$ psu dan di bagian dasar perairan $<31,4$ psu.
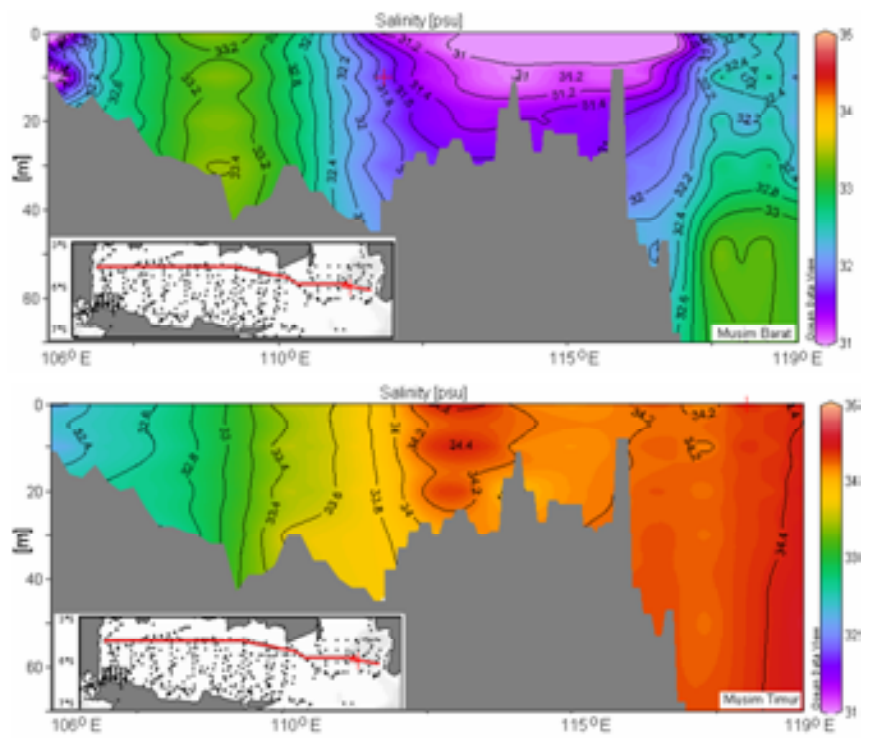

Gambar 8. Distribusi vertikal salinitas musim barat (atas) dan musim timur di Laut Jawa (bawah).

Figure 8. Vertical distribution of salinity during West a periode of monsoon (above) and on Eastnorthwest monsoon (below) in Java Sea. 
Periode muson tenggara di mana curah hujan sangat kecil, distribusi vertikal salinitas lebih homogen (Gambar 8b). Intrusi massa air oseanik bersalinitas tinggi dari arah timur menuju ke barat Laut Jawa sangat jelas terlihat mulai dari permukaan sampai dengan dasar perairan. Pengaruh massa air tawar sama sekali tidak terlihat di sekitas pantai selatan Kalimantan, karena limpasan debit air tawar dari sungai-sungai yang bermuara ke Laut Jawa pada periode muson tenggara sangat kecil (Sadhotomo, 2006).

\section{Distribusi Konsentrasi Klorofil-a}

Distribusi horisontal konsentrasi klorofil-a rata-rata bulanan menunjukkan bahwa secara umum konsentrasi klorofil-a lebih tinggi di sekitar pantai dan semakin menjauhi pantai konsentrasi menurun menjadi $<0,5 \mathrm{mg} \mathrm{m}^{-3}$ (Gambar 9). Konsentrasi klorofila di bagian timur (4-6 $\left.6^{\circ} \mathrm{LS}: 114-118^{\circ} \mathrm{BT}\right)$ yakni di sekitar pantai Kalimantan lebih tinggi dibandingkan dengan wilayah bagian tengah (4-6 $\left.{ }^{\circ} \mathrm{LS}: 108-114^{\circ} \mathrm{BT}\right)$ seperti tertera pada Gambar 10a. Konsentrasi klorofil-a di bagian tengah yakni di sekitar pantai Kalimantan ratarata $>3 \mathrm{mg} \mathrm{m}^{-3}$ tergolong tinggi untuk menghasilkan produktivitas primer dan bagi makanan biota laut (larva udang, ikan, dan lain lain) (Kaswadji, 2006).

Hasil penelitian sebelumnya menunjukkan bahwa laju produktivitas primer permukaan yang tinggi di laut terjadi di sekitar pantai. Produktivitas tertinggi adalah $39,11 \mathrm{mg} \mathrm{C}$.hour ${ }^{-1} \cdot \mathrm{m}^{-3}$, berada di sekitar daerah estuaria Sungai Borneo. Produktivitas primer rata-rata adalah setengah dari nilai maksimum dan terendah adalah $0,05 \mathrm{mg} \mathrm{C}$.jam ${ }^{-1} \cdot \mathrm{m}^{-3}$ (Soegiarto \& Nontji, 1966). Kecenderungan bahwa laju produksi yang lebih tinggi terjadi dari barat menuju timur Laut Jawa. Hal ini, terlihat dari distribusi horisontal konsentrasi klorofil-a yang terkonsentrasi di bagian timur dekat perairan pantai Kalimantan (114-116 $\left.{ }^{\circ} \mathrm{BT}\right)$ seperti tertera pada Gambar 10a.

Secara temporal, puncak konsentrasi klorofil-a terjadi pada bulan Desember sampai dengan Maret di mana curah hujan relatif tinggi (Gambar 10b). Periode ini merupakan periode muson barat laut di
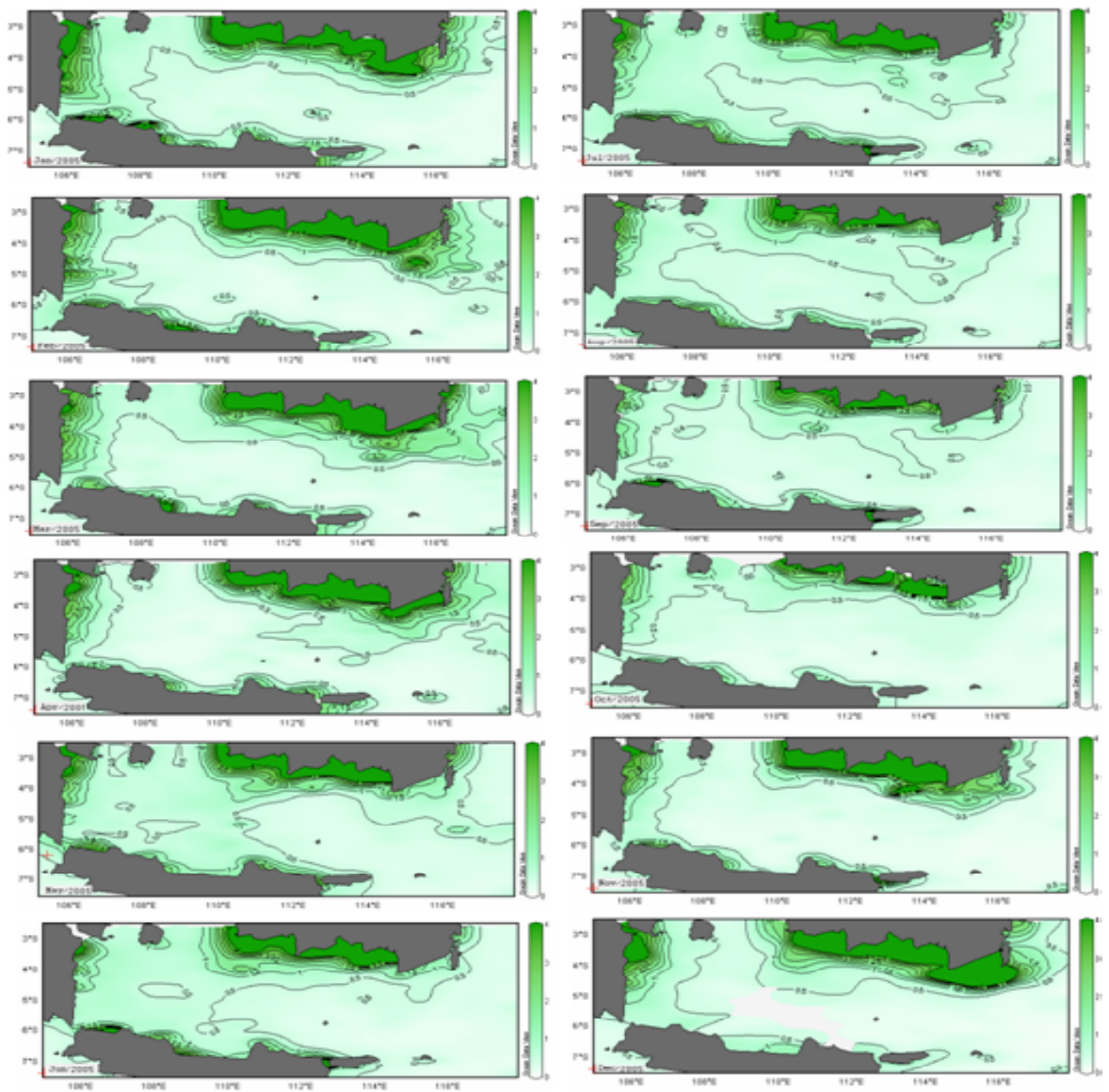

Gambar 9. Distribusi konsentrasi klorofil-a rata-rata bulanan (bulan Januari sampai dengan Desember) di Laut Jawa (2005).

Figure 9. Monthly mean concentrations distribution of cholorophyll-a (January - December) in Java Sea (2005). 
mana curah hujan relatif tinggi (Sadhotomo, 2006). Masukan material termasuk unsur-unsur nutrien dari limpasan sungai-sungai khususnya pada musim penghujan diduga merupakan salah satu faktor penyebab tinggi konsentrasi klorofil-a.
Fitoplankton adalah organisme tumbuhan yang mengandung klorofil-a dan merupakan produser primer yang mengkonversi bahan anorganik (misal nitrat dan fosfat) menjadi senyawa organik yang baru (misal lemak dan protein) lewat proses fotosintesis dan mengawali rantai makanan di laut. Kesuburan biologis suatu perairan dapat dikatakan dengan nilai
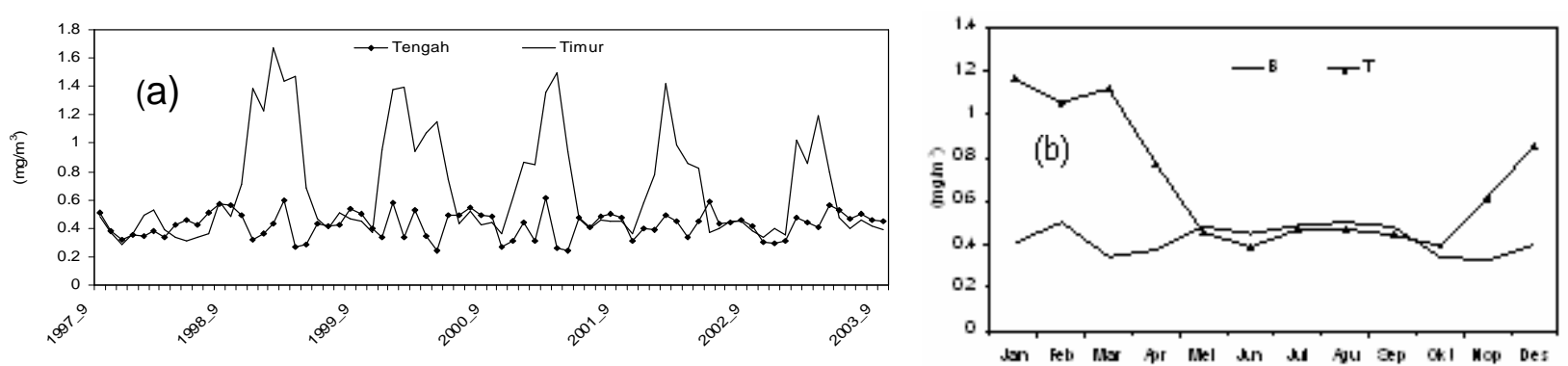

Gambar 10. a) Konsentrasi klorofil-a rata-rata bulanan (tahun 1997 sampai dengan 2005) pada posisi (4$6^{\circ}$ LS: $\left.108-114^{\circ} \mathrm{BT}\right)$ dan (4-6 $\left.6^{\circ} \mathrm{LS}: 114-118^{\circ} \mathrm{BT}\right)$ dan b) rata-rata selama 6 tahun.

Figure 10. a) Monthly mean concentration of cholorophyll-a (1997-2005) in (4-6 $6^{\circ}$ LS: 108-114 BT), and in (4-6 $6^{\circ}$ LS: $114-118^{\circ}$ BT) and b) Monthly mean during 6 years.

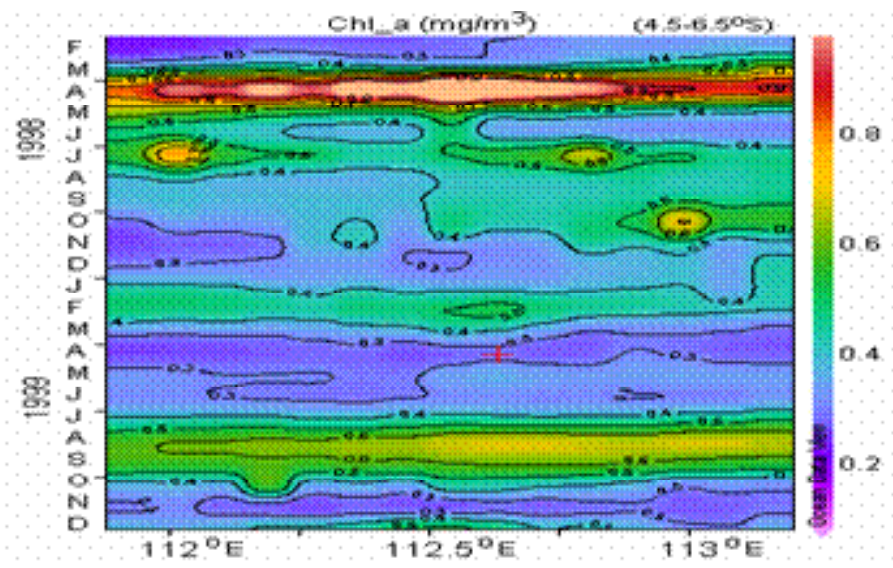

Gambar 11. Time longitude plot konsentrasi klorofil-a dari citra satelit SeaWiFS di Laut Jawa.

Figure 11. Time longitude plot of cholorophyll-a concentrations from SeaWiFS satellite images in Java Sea.

konsentrasi korofil atau kelimpahan fitoplankton. Semakin tinggi nilai klorofil-a akan semakin tinggi kesuburan (Kaswadji, 2006).

Berdasarkan pada hasil analisis spektral rata-rata konsentrasi klorofil-a di wilayah 5,5-6,5 LS dan 104$108^{\circ} \mathrm{BT}$ terlihat signal yang signifikan dengan periode annualdan interannual, yang merupakan refresentasi dari pengaruh muson dan perbahan iklim global seperti ENSO dan dipole mode.

Pada saat ENSO/DM tahun 1997 atau 1998, terjadi anomali positif konsentrasi klorofil-a (Gambar 11). Pada saat ENSO, di wilayah Indonesia curah hujan sangat rendah dan intensitas matahari menjadi lebih tinggi. Tinggi intensitas penyinaran matahari diduga menjadi salah satu faktor penyebab tinggi konsentrasi klorofil-a pada saat kejadian ENSO.

\section{Variasi Paramater-Parameter Oseanografi dan Hasil Tangkapan Ikan}

Distribusi suhu dan salinitas antara periode muson tenggara dan barat laut menunjukkan perbedaan yang nyata. Hal ini, berpengaruh terhadap distribusi sumber daya ikan di Laut Jawa sebagaimana telah dikatakan beberapa peneliti sebelumnya, pada periode muson tenggara, di mana terjadi intrusi massa air oseanik dengan salinitas tinggi juga diikuti oleh penetrasi ikan- 

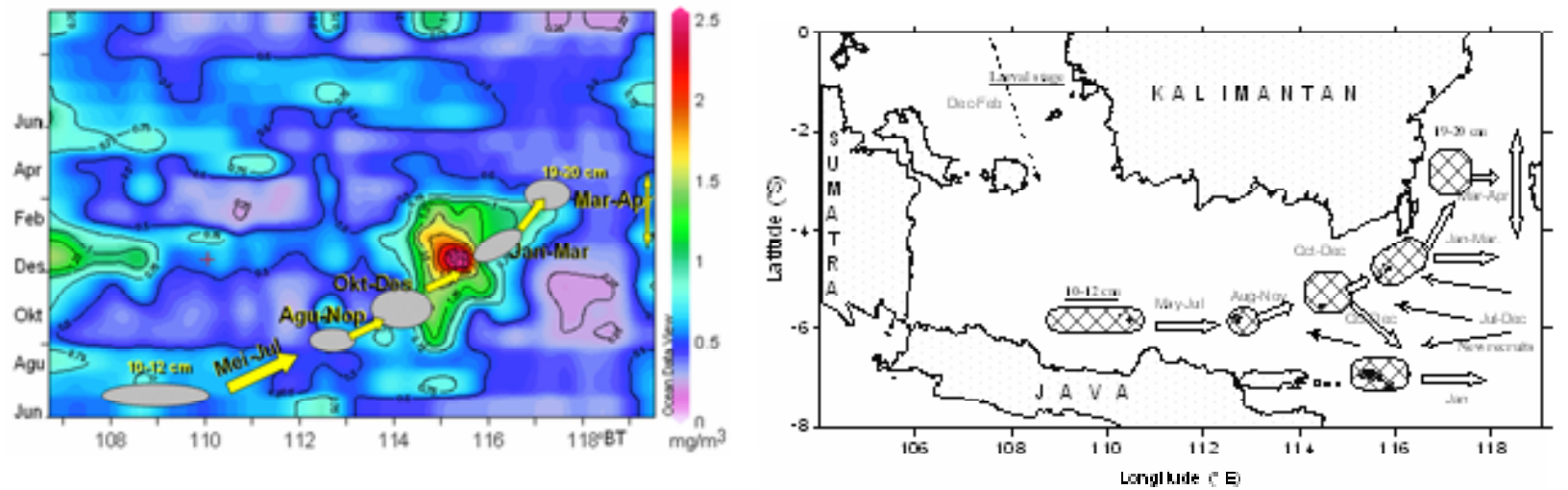

Gambar 12. Distribusi konsentrasi klorofil-a (time longitude) dan migrasi internal ikan pelagis di Laut Jawa.

Figure 12. Concentration distribution of chlorophyll-a (time latitude) and internal migration of fish in Java Sea.

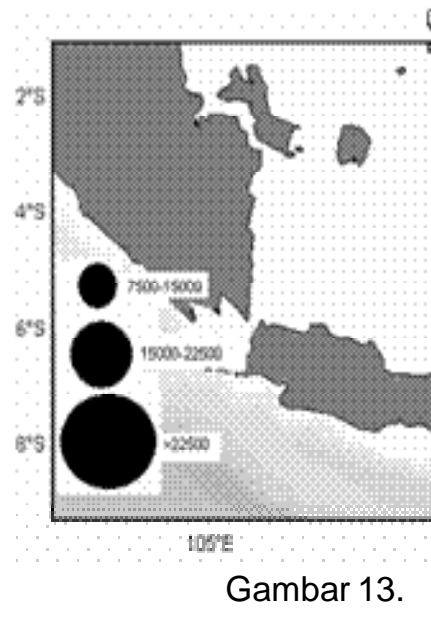

Figure 13. (a).

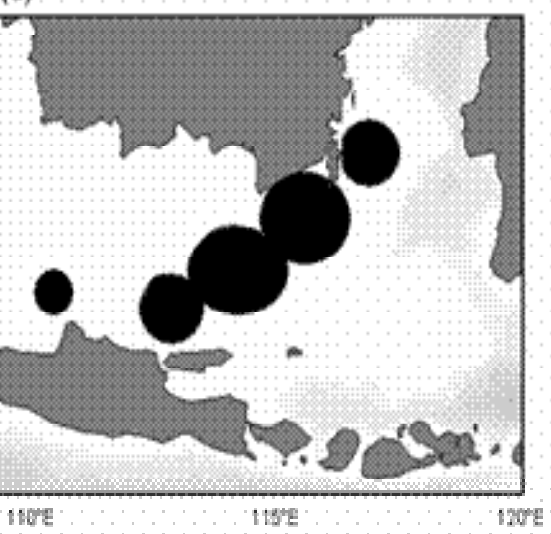

(b)

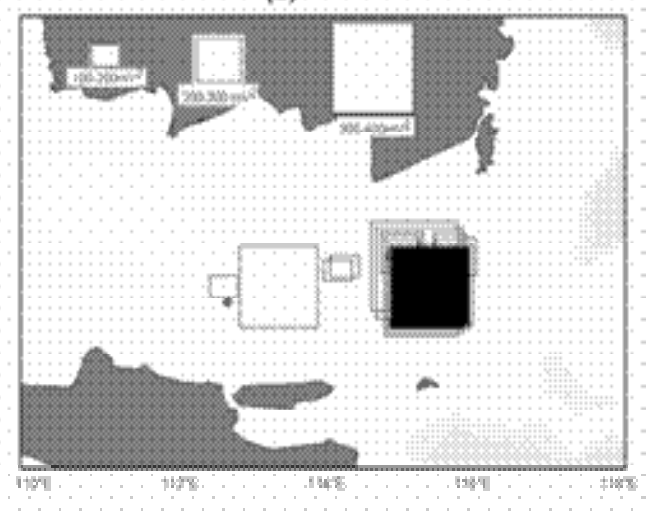

Kepadatan ikan di Laut Jawa a) data tangkapan dan b) survei akustik. Sumber: Atmaja et al. (2003)

Fish density in Java Sea a) fish catch data and b) acoustic survey Sources: Atmaja et al. (2003)

ikan oseanik ke Laut Jawa seperti jenis ikan layang, sebaliknya terjadi pada musim muson barat laut. (Potier, 1998 dalam Atmaja et al., 2003).

Secara spasial, terjadi pergerakkan konsentrasi klorofil-a di mana antara bulan Oktober sampai dengan Desember, konsentrasi klorofil meningkat secara tajam di bagian timur Laut Jawa (115-117 BT) yang berdekatan dengan pantai selatan Kalimantan. Terlihat ada sinkronisasi antara migrasi internal ikan pelagis (Gambar 12) (Sadhotomo, 2006) dengan pola distribusi konsentrasi klorofil-a. Demikian juga, kepadatan ikan pelagis cendrung terkonsentrasi di lokasi bagian timur Laut Jawa baik dari pengamatan hasil tangkapan maupun hasil deteksi echosounder seperti tertera pada Gambar 13 (Atmaja et al., 2003). Hal ini, menunjukkan bahwa selain parameterparameter lingkungan fisik, parameter lingkungan biologi juga mempengaruhi distribusi dan kelimpahan ikan di Laut Jawa.

Berdasarkan pada analisis parameter suhu dan konsentrasi klorofil-a, di Laut Jawa terlihat pengaruh ENSO terhadap variabilitas parameter tersebut. suhu permukaan laut mengalami anomali negatif sekitar $\left(2^{\circ} \mathrm{C}\right)$ pada tahun 1991 , sedangkan konsentrasi klorofil di wilayah bagian tengah Laut Jawa mengalami anomali positif. Sadhotomo (2006), telah mengatakan bahwa pada periode tahun 1991 sampai dengan 1992 variasi distribusi dan frekuensi panjang dan rekruit baru dari $D$. russelli masuk ke Laut Jawa kelihatan lebih bervariasi dari tahun-tahun yang lain Gambar 14.

Secara teoritis, ada beberapa kemungkinan faktor yang berpengaruh terhadap variabilitas interannual laju pertumbuhan ikan pelagis di Laut Jawa. Salah satu 


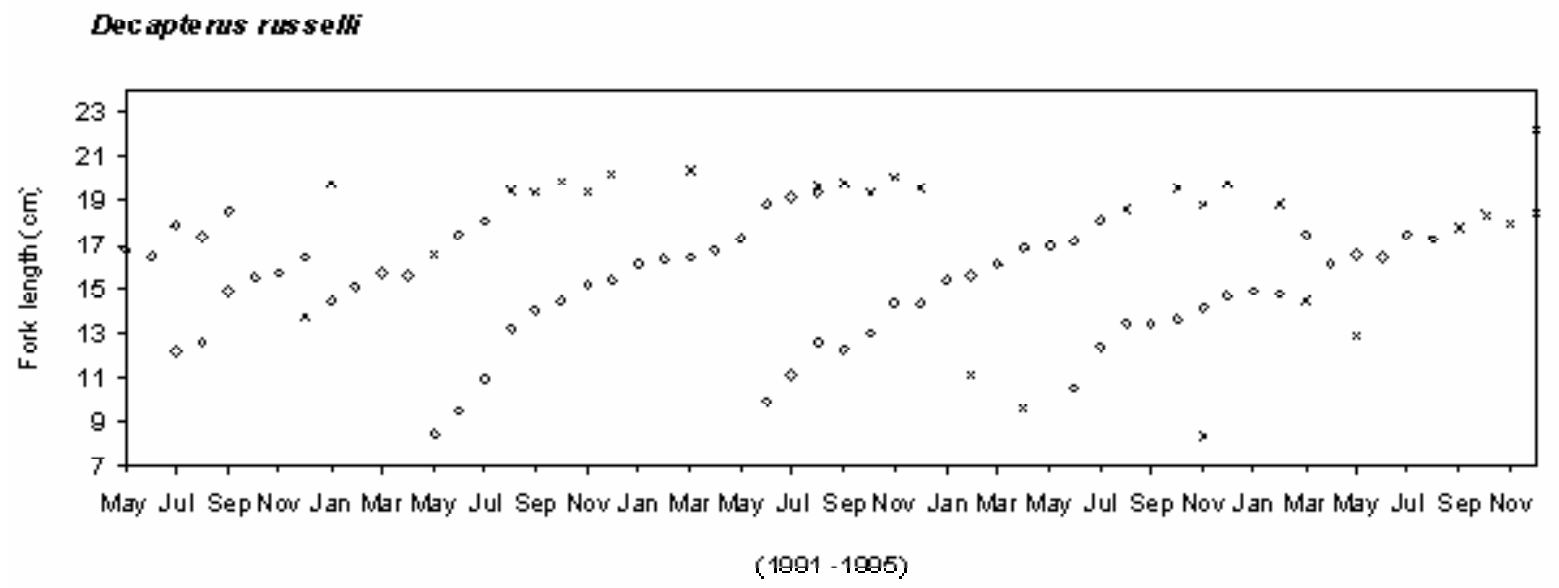

Gambar 14. Panjang rata-rata bulanan dari data frekuensi panjang ikan $D$ ruselli tahun 1991 sampai dengan 1995.

Sumber: Sadhotomo (2006)

Figure 14. Monthly mean length derived from length frequency data of D ruselli in 1991 - 1995.

Sources: Sadhotomo (2006)

faktor adalah perubahan interannual makanan dalam batas adaptasi spesies, di mana fenomena ini terlihat pada Japanese sardine berdasarkan pada evaluasi data jangka panjang kelimpahan dan estimasi parameter pertumbuhan (Wada \& Kashiwai, 1991).

Hasil-hasil penelitian sebelumnya juga menemukan ada perubahan komposisi hasil tangkapan pada tahun 1991 sampai dengan 1992, yakni tertangkap spesies yang lain dalam jumlah banyak seperti ikan swangi (Priacanthus macrachantus). Demikian juga, pada kejadian ENSO tahun 1997 sampai dengan 1998, ditemukan jenis ikan cekong (Sardinellasp.) di daerah penangkapan pesisir pantai Selat Sunda dan ikan ayam-ayaman (Alesterus monoceros) yang mendominasi hasil tangkapan pukat cincing di bagian timur Laut Jawa. Ikan ini mendominasi hasil tangkapan mencapai $40 \%$ dengan laju tangkap 16,7 ton per trip (Atmaja et al., 2003).

Menurut Laevastu (1993), anomali suhu dapat menyebabkan perubahan dalam waktu puncak pemijahan dan perubahan lokasi pemijahan dari lokasi pemijahan tradisional. Oleh karena itu, ada dugaan masuk kelompok umur ikan tertentu ke Laut Jawa pada saat ENSO. Selanjutnya, disebutkan juga bahwa agregasi ikan dipengaruhi beberapa aspek phsico cehemicaldan kondisi biologi lingkungan. Perubahan kondisi lingkungan fisik dan biologi yang terjadi pada saat ENSO tahun 1997 atau 1998 diduga menjadi penyebab terjadi agrerasi jenis ikan tertentu di Laut Jawa.

\section{KESIMPULAN}

1. Analisis parameter-parameter oseanografi seperti suhu, salinitas, dan konsentrasi klorofil-a menguatkan hasil-hasil penelitian sebelumnya yang menunjukkan bahwa variabilitas parameterparameter oseanografi di Laut Jawa secara kuat dipengaruhi pergerakkan angin muson. Pada periode musim angin muson tenggara, suhu permukaan laut di Laut Jawa lebih rendah, namun salinitas meningkat dan sebaliknya terjadi pada saat musim muson barat laut. Konsentrasi klorofila di bagian barat Laut Jawa relatif sama pada ke2 musim, tetapi di bagian timur Laut Jawa, konsentrasi klorofil-a meningkat pada musim barat.

2. Selain pengaruh angin muson, perubahan iklim global ENSO juga terlihat mempengaruhi parameter suhu dan konsentrasi klorofil-a. Pada saat ENSO, terjadi anomali negatif suhu permukaan laut yang menurun sampai dengan mencapai suhu $25,3^{\circ} \mathrm{C}$, sebaliknya di bagian timur Laut Jawa terjadi anomali positif konsentrasi klorofil-a.

3. Variasi parameter-paramater oseanografi yang terjadi di Laut Jawa baik yang berhubungan dengan perubahan musim maupun iklim global 
berpengaruh terhadap distribusi, dan kelimpahan ikan. Oleh karena itu, data parameter-parameter oseanografi yang secara terus-menerus diamati khususnya dari citra satelit sebaiknya digunakan sebagai informasi untuk pengelolaan sumber daya ikan secara optimal dan lestari di Laut Jawa.

\section{PERSANTUNAN}

Kegiatan dari hasil riset strategi kebijakan Teluk Tomini dan Laut Jawa, T.A. 2006, di Pusat Riset Perikanan Tangkap, Ancol-Jakarta.

\section{DAFTAR PUSTAKA}

Allan, R., Lindesay J., \& Parker D. 1996. El Nino southern oscillation and climatic variability. CSISO Publishing Vitoria. Australia.

Atmaja, S. B., D. Nugroho, Suwarso, T. Hariati, \& Mahisworo. 2003. Pengkajian stok ikan di wilayah pengelolaan perikanan Laut Jawa. Prosiding Pengkajian Stok Ikan Laut 2003. Pusat Riset Perikanan Tangkap. Departemen Kelautan dan Perikanan.

Durand, J. R. \& Petit. D. 1995. The Java Sea environment. In M. Potier \& S. Nurhakim (eds). Seminar on the Biology, Dynamics, and Exploitations. Java Sea Pelagic Fishery Assessment Project. Jakarta.

Kaswadji, R. 2006. Kesuburan biologi lingkungan Laut Arafura in presfektif pengelolaan sumber daya perikanan tangkap Laut Arafura. Departemen Pemanfaatan Sumber Daya Perikanan. Institut Pertanian Bogor. 47-66.

Laevastu, T. 1993. Marine climate, weather, and fisheries. Fishing News Books. London.
Meyers, G. 1996. Variation Indonesian thoroughflow and El Nino southern oscillation. Journal Geophy. Resources. 101.1.225-12.263.

Potier, M. \& Boely. T. 1990. Influence de parametre de l'environnement sur la peche a la senne tournante et coulissante en mer de Java. Aquatic Living Resources. 3. 193-205.

Qu, T, Y. Du, J. Strachan, G. Meyers, \& J. Slingo. 2005. Sea surface temperature and its variability in the Indonesian region. Journal Oceanography. 18: 50-61.

Sadhotomo, B. 2006. Environment feature of the Java Sea (in press).

Population dynamics of the main pelagic species exploited in the Java Sea. Part I: Biological Parameters Estimates (In press).

Saeger, J., Martosubroto P., \& Pauly D. 1976. First report of the Indonesian-German demersal fisheries project. Result of a Trawl Survey in the Sunda Shelft Area. Marine Fisheries Resources Ins. and German Ag. Tech. Coo. (GTZ).

Soegiarto, A. \& Nontji, A. 1966. A seasonal study of primary marine productivity in Indonesian waters. $X I$ th Pacific Science Congress. Tokyo. 7 p.

Wada, T. \& Kashiwai, I. 1991. Change in growth and feeding ground of japanese sardine with fluctuation in stock abundance. In Kawasaki, T., Tanaka S., Toba Y., \& Taniguchi, A. (eds). Long term variability of pelagic fish populations and their environment. Pergamon Press. 181-190.

Wyrtki, K. 1957. Die zirkulation onder oberflache der sudostasiatischen gewasser. Deutsch Hydrographische Zeitschrift. Band 10. Heft 1. 113.

Wyrtki, K. 1961. Physical oceanography of the south east Asian waters. Naga Report. 2. 1-145. 